Article

\title{
Delineating the Drainage Structure and Sources of Groundwater Flux for Lake Basaka, Central Rift Valley Region of Ethiopia
}

\author{
Megersa Olumana Dinka \\ Department of Civil Engineering Science, Faculty of Engineering and the Built Environment, University of \\ Johannesburg APK Campus, Johanneburg 524, South Africa; magarsol@yahoo.com; Tel.: +27-011-559-2540
}

Received: 15 September 2017; Accepted: 10 October 2017; Published: 29 November 2017

\begin{abstract}
As opposed to most of the other closed basin type rift valley lakes in Ethiopia, Lake Basaka is found to be expanding at an alarming rate. Different studies indicated that the expansion of the lake is challenging the socio-economics and environment of the region significantly. This study result and previous reports indicated that the lake's expansion is mostly due to the increased groundwater (GW) flux to the lake. GW flux accounts for about $56 \%$ of the total inflow in recent periods (post 2000) and is found to be the dominant factor for the hydrodynamics and existence of the lake. The analysis of the drainage network for the area indicates the existence of a huge recharge area on the western and upstream side of the catchment. This catchment has no surface outlet; hence most of the incoming surface runoff recharges the GW system. The recharge area is the main source of GW flux to the lake. In addition to this, the likely sources/causes of GW flux to the lake could be: (i) an increase of GW recharge following the establishment of irrigation schemes in the region; (ii) subsurface inflow from far away due to rift system influence, and (iii) lake neotectonism. Overall, the lake's expansion has damaging effect to the region, owing to its poor water quality; hence the identification of the real causes of GW flux and mitigation measures are very important for sustainable lake management. Therefore a comprehensive and detailed investigation of the parameters related to GW flux and the interaction of the lake with the GW system of the area is highly recommended.
\end{abstract}

Keywords: Basaka Lake; hydrologic models; groundwater fluxes; lake level; stream networking; quantification and modelling

\section{Introduction}

Most of the closed-basin type Main Ethiopian Rift Valley (MERV) lakes are experiencing water level and salinity fluctuations [1-10], mostly shrinkages in size. Lake Basaka is found to be unique compared to the terminal lakes within the MERV region due to the fact that the water is expanding at a very fast rate and is not usable for irrigation or drinking purposes $[7,8]$. Surprisingly, the surface area of the lake increased from $2.7 \mathrm{~km}^{2}$ in 1957 to more than $50 \mathrm{~km}^{2}$ in 2015 [10]. See Figure 1a-c for the location and expansion extent of the lake $[8,10]$. The fluctuation of the lake's water is in response to the changes in the surface- and sub-surface components of the lake's water balance. The expansion extent and hydrochemical characteristics of the lake have been well documented by different researchers [1-8,11-18]

The expansion of Lake Basaka, owing to its poor water quality, is threatening the socio-economics and environment of the region significantly [10]. Different study reports $[7,10,19,20]$ indicated that the lake's expansion is affecting the irrigation development, pastoralism, infrastructure, and the ecosystem of the region (see Figure 1d,e). A study made by Dinka [7,10] clearly indicated that the expansion of the lake is affecting the regimes of soil and water quality of Matahara Sugar Estate (MSE) and challenging the sustainability of production and productivity significantly. The sugar estate also lost more than 
300 ha of productive lands due to inundation by lake and salt encroachment $[6,10]$. The lake's expansion is also threatening the existence of nearby towns (Matahara and Fantalle) and the sustainability of downstream irrigation developments within the Awash River basin. The lake also inundated the major railway (Addis Ababa-DireDawa-Djibouti) and highway (Addis Ababa-DireDawa/Harar) lines and caused the reconstruction of new railways and highway lines with a huge investment $[7,8]$. The lake has inundated significant grazing lands and hence seriously threatened the existence of the Karayyuu (indigenous) pastoralists $[7,8,10,19,20]$. Belay [6] indicated that the lake's expansion has created an unstable transitional zone between the wetland and the nearby terrestrial ecosystem; hence she described it as a natural disaster for the ecosystem of the region.

As a permanent and expanding lake, the interaction of Lake Basaka with the surrounding (surface, atmospheric, and subsurface) water systems is highly expected. Permanent lakes usually interact with the surrounding groundwater (GW) system in three main ways [21]: some receive GW inflows, some have seepage loss to the GW, and others receive from and lose to the GW system [9]. There are various methods of quantifying the lake water-groundwater interaction: the measurement of seepage using flownet or seepage meters [22-24], simulation (mathematical) models based on Darcy's law [25-27], the heat tracer method [23,28,29], the water budget method [30-32], the chemical/solute mass balance method [32-35], or the use of stable isotopes [26,36]. Detailed reviews of the different GW flux estimation methods are well documented [22,23,26,36].

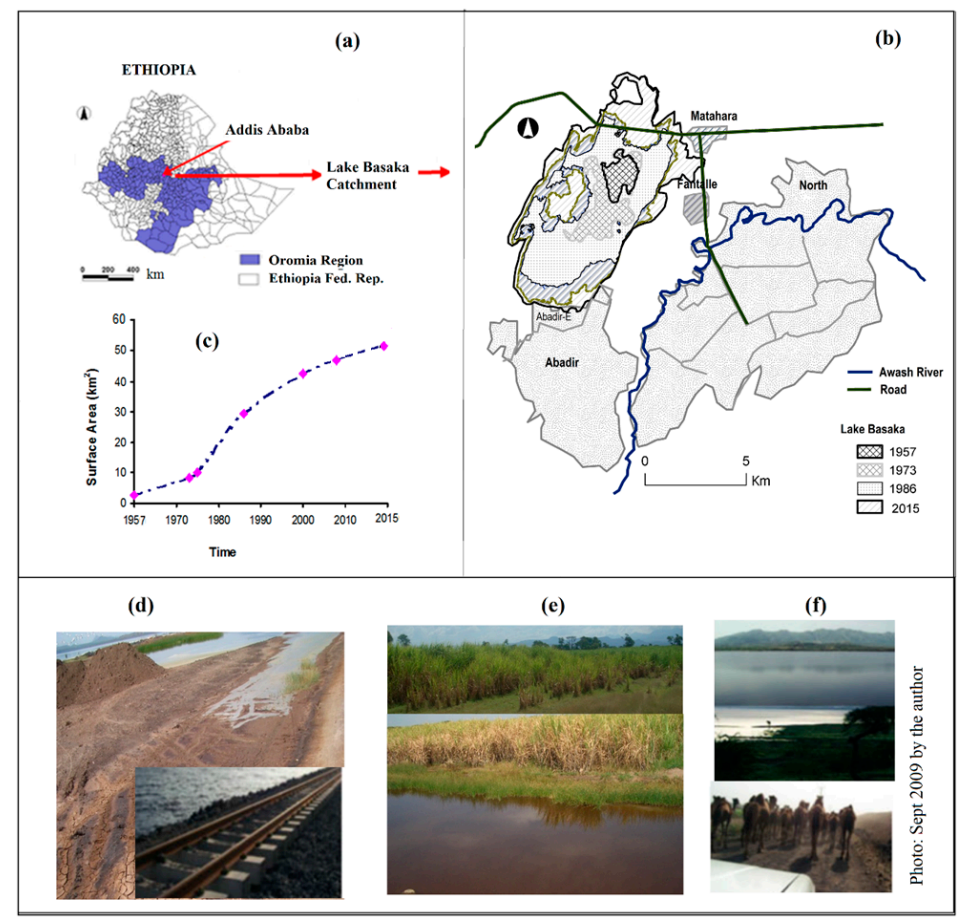

Figure 1. Expansion of Lake Basaka and its effects on the region. (a) The location of the Lake Basaka catchment in Ethiopia; (b,c) the expansion extent and surface area of Lake Basaka (1957 to 2015), including Matahara Sugar Estate and Awash River [10]; (d) the effect of lake expansion on infrastructures (dyke construction and railway/highway lines); (e) the effect of Lake Basaka's expansion on Matahara Sugar Estate (Abadir farm), the lake's emergence in Abadir, the extension fields during the rainy season, and the stunted growth of sugarcane crop; $(\mathbf{f})$ the effect of the lake's expansion on grazing land, pastoralists, and ecosystem balance.

Various research reports $[3,6,7,9,14,16]$ indicated that the GW contribution to Lake Basaka is more than $50 \%$ of the total inflow. Recent studies [7,9] quantified the amount of GW contribution in different hydrologic years (1970 up to 2010) using a conceptual water balance model. Based on their finding, GW flux is responsible for the existence and expansion of the lake in recent times. However, 
the possible sources/causes for GW flux to the lake are not fully identified yet, except for views and suggestions. Most of the previous scholars generally relate it to increased GW recharge upstream due to the establishment of irrigation schemes $[3-5,9,14,16]$, and others are relating it to leakage from the Awash River [2,5,14] and lake neotectonisim [4,5,11,16,22]. No comprehensive and critical research has been done so far regarding the possible causes/sources of GW flux to the lake. Dinka [7] indicated that a lack of detailed and comprehensive investigation that explains the possible source/causes for GW flux is challenging the measures to be taken to minimize (or prevent) the expansion of the lake and its possible threats to the Matahara region in particular and the irrigation development within Awash basin in general.

The objectives of the current study are: (i) to synthetically delineate the drainage structure of the lake catchment; (ii) to present the dynamics of the lake's water balance in different hydrologic years (1960 to 2010); and (iii) to suggest the potential sources/causes of GW flux. The dynamics (seasonal, annual, and decedal) of GW flux to the lake in different hydrologic years and its potential sources are presented. There is no previous study related to the time-series (seasonal, annual, and decadal) GW flux to the lake. This condition makes the current study very special and informative.

\section{Lake Basaka Catchment Description}

This section presents a detailed description of the lake's catchment, including its physical characteristics, climate, soils, vegetation, hydrology, geology, and rift structure.

\subsection{Physical Characteristics}

Lake Basaka is a volcanically dammed, endorheic lake located in the Middle Awash River Basin of Ethiopia, in the northern part of the MERV, at a close distance to the Afar triangle [6,7]. It has variable depth, ranging from 1.5 to $13 \mathrm{~m}$ (2015 estimate). The deepest part of the lake is located in the north-central part, which is the original lake location, before it started expanding (see Figure 1b). Then, the lake water expanded to the other areas when the equilibrium of the lake's water balance (i.e., hydrologic cycle) was disturbed by a net influx of water to the lake [6]. The total surface water catchment of the lake is about $500 \mathrm{~km}^{2}$, and it receives an annual rainfall of approximately 0.28 billion $\mathrm{m}^{3}$ (2015 estimate). The lake catchment has variable altitude, ranging from very flat areas (950 $\mathrm{m}$ a.s.l.) to undulating plains $(1100 \mathrm{~m})$, hills $(1500 \mathrm{~m})$ to high mountains $(1900 \mathrm{~m})$. The highest altitude (1940) is located at Fantalle Crater, a volcanic mountain located in the northern part of the lake and believed to be created by the recent volcano that occurred in the region at the end of the Eighteenth Century [7]. Topographically, the lake water is located at the lowest elevation (Figure 2), where all the incoming surface runoff and sediment from its catchment are accumulated [7]. That means the sediment trapping efficiency of the lake is $100 \%$. The physical characteristics of Lake Basaka and its catchment are summarized in Table 1.

Table 1. Physical characteristics of Lake Basaka and its catchment.

\begin{tabular}{clcc}
\hline S.N & \multicolumn{1}{c}{ Parameter $^{* *}$} & Symbol & Value \\
\hline 1. & Latitude (UTM) & La & 595,000 \\
2. & Longitude (UTM) & Lo & 983,000 \\
3. & Altitude (water surface) $(\mathrm{m})$ & $\mathrm{E}$ & 951 \\
4. & Minimum depth $(\mathrm{m})$ & $\mathrm{mD}$ & 1.5 \\
5. & Maximum depth $(\mathrm{m})$ & $\mathrm{MD}$ & $13^{*}$ \\
6. & Mean depth $(\mathrm{m})$ & $\mathrm{D}$ & $7.5^{*}$ \\
7. & Surface area $\left(\mathrm{km}^{2}\right)$ & $\mathrm{A}_{\mathrm{L}}$ & $52^{*}$ \\
8. & Lake Volume $\left(\mathrm{Mm}^{3}\right)$ & $\mathrm{V}$ & $220^{*}$ \\
9. & Catchment Area $\left(\mathrm{km}^{2}\right)$ & $\mathrm{A}_{\mathrm{C}}$ & 500 \\
10. & Mean Width $\left(\mathrm{km}^{2}\right)$ & $\mathrm{W}$ & $4.1^{*}$ \\
11. & Length of shoreline circumference $(\mathrm{km})$ & $\mathrm{L}$ & $50.8^{*}$ \\
\hline
\end{tabular}

Note: ${ }^{*} 2015$ estimates; ${ }^{* *}$ the values in parenthesis are units. 


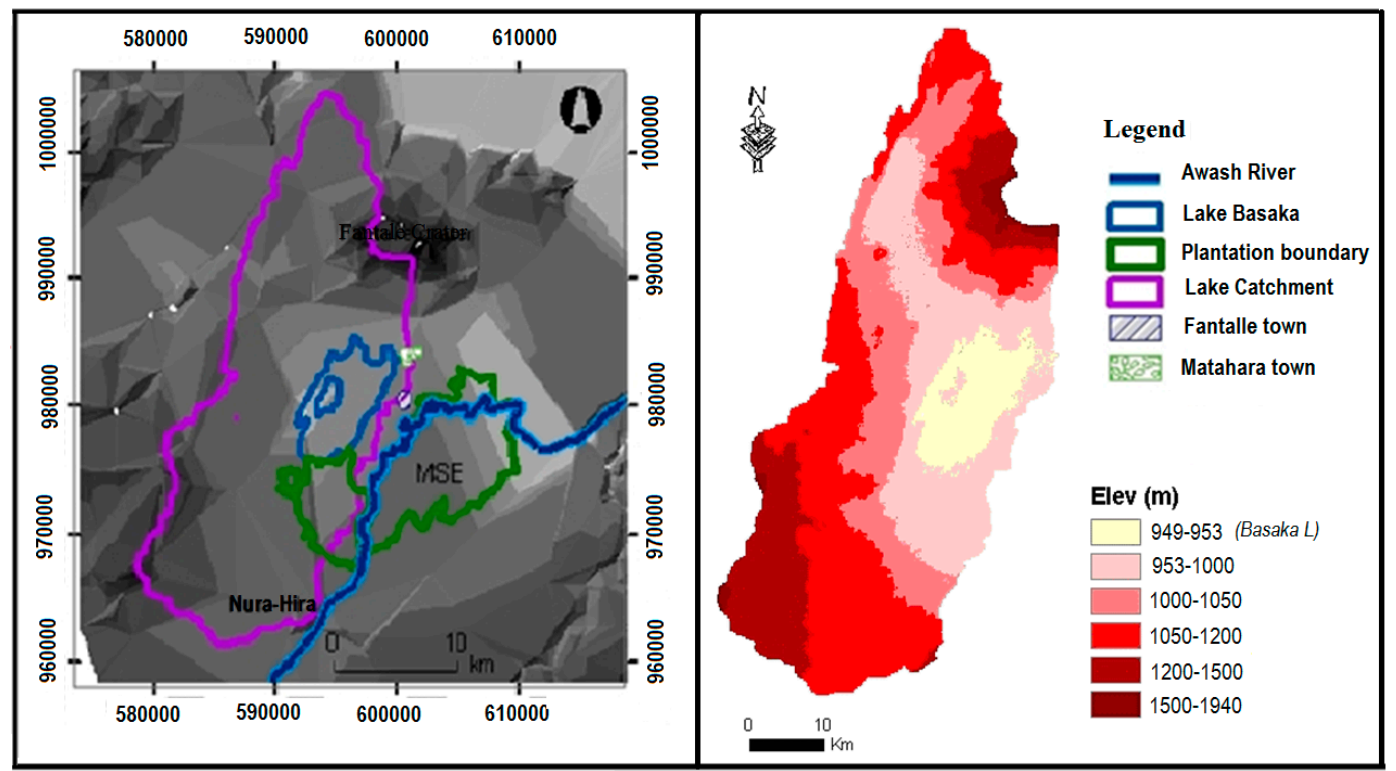

Figure 2. Lake Basaka catchment and the surrounding areas extracted from DEM [7,8]. MSE-Matahara Sugar Estate, DEM-Digital Elevation Model.

\subsection{Climate}

The Matahara plain area, including Lake Basaka, has the characteristics of a semi-arid climate with a bimodal and erratic rainfall distribution pattern $[7,8]$. The main rainy season occurs from July to September and accounts for about $70 \%$ of the total rainfall of the area. The minor rain season, which accounts for about $30 \%$ of the total rainfall, occurs occasionally from February/March to April. The occurrence of occasional minor rainfall in March/April is related to the effect of the Inter Tropical Convergence Zone (ITCZ) or monsoon winds on the Ethiopian climate. The long years' average (1966 to 2015) mean annual rainfall and the temperature of the area are $541.7 \mathrm{~mm}$ and $26.3^{\circ} \mathrm{C}$, respectively. The average annual pan evaporation and sunshine hours of the area are about $2518 \mathrm{~mm}$ and $8.25 \mathrm{~h}$, respectively. The relative humidity of the area is in the range of $29.3 \%$ to $82.4 \%$.

\subsection{Soils and Vegetation Cover}

Lake Basaka catchment has variable soil types and land use-land cover (LULC) types [6,7,37]. Details of the soil types and land cover characteristics of Lake Basaka catchment are presented in Figure 3, which was obtained from Dinka [38]. The major soil types are Cambisols, Fluvisols, Luvisols, Lepthosols, Podzoluvisols, Solonchak, and mountain soils (Figure 3b). Almost half of the soil in the area is covered by Lepthosols and Cambisols. Lepthosols, the predominant soil type in the catchment (33\%), are characterised by shallow soil with a weakly developed, coarse textured soil structure, occupying the western part of the catchment and mainly covered by open bushy woodlands. Cambisols are well-drained, deep, and medium- to coarse-textured soils, mainly occupying the northern part of the catchment (west part of the lake) and are mainly covered by open grass and bush lands. Podzoluvisols are well-drained, very deep, medium to coarse textured soils with moderately developed structures, mainly found in the south-eastern part of the catchment. The solonchak soils are poorly drained, deep, have a weak to moderately developed structure, are mainly found along the eastern edge of the lake, and are characterised by salt crust at the surface [6]. Luvisols are soil units mostly occupied by the Abadir farm (south of the lake) and the Nura-Era farm (south-west of the lake). The northern part of the lake is covered by basaltic (AA type) lava flow soils, characterised by inverted properties Most of this lava flow area is currently inundated by the lake. 


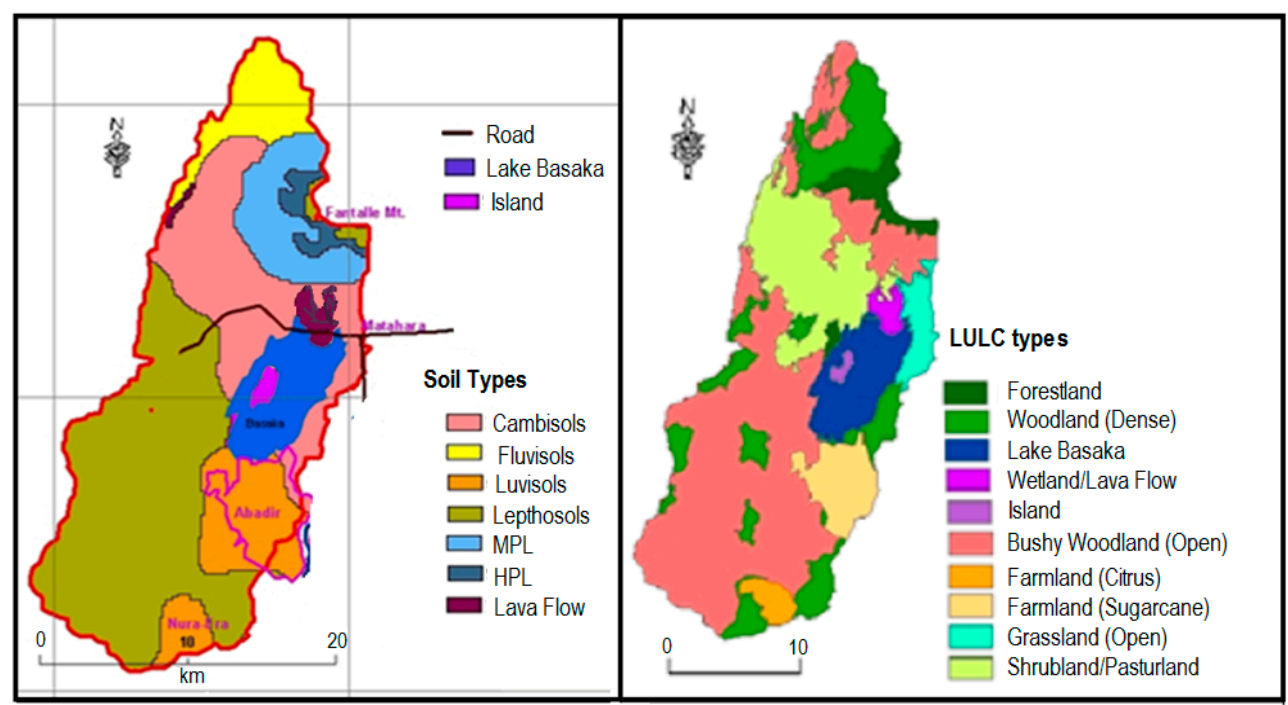

(a)

(b)

Figure 3. (a) Soil types, and (b) land use/cover conditions of the Lake Basaka catchment [38]. (Note that the shape of lake shown in the map is that of the year 2000 (left) and 2007 (right)).

\subsection{Hydrogeology and Rift Structure}

As indicated by the United Nations' hydrogeological map of Africa [39], the hydrogeology of the volcanic rocks covering the Great East African Rift Valley (GEARV) region is classified as "the most complex and least understood" [40]. Very few hydrogeological studies [9,11,37,40-42] have been carried out in the Lake Basaka area [6] and the surrounding regions. The lake catchment is located in the active part of the MERV, a geologically unstable area. The MERV is characterized by active volcanic activates and structural deformations, especially along the NNE-SSW belts $[43,44]$. The volcano-tectonic belts were formed during the quaternary period by young faults, fractures and volcanic centers on the rift floor [6,44].

The Lake Basaka catchment aquifers are part of the Fantalle volcano-complex and are mainly alluvial/lacustrine sediments, ignimbrites, and basalts [40]. The Fantalle volcano complex consists of two caldera volcanoes (the older and younger Fantalle) [6]. A substantial portion of the south-western part of the lake's catchment is covered by undifferentiated lava flow of trachytic to rhyolitic composition with minor ignimbrite intercalations. The area is situated on the axial position of the rift floor in the northern part of the MERV, at the junction between the Ethiopian Rift and the Afar triangle. Thus, the region is located at the junction of several faults systems (the NNE, EW, and NS faults) of the Afar depression [40]. Its location within active magmatic segments makes it susceptible to intense volcanic and related tectonic activities. Furthermore, its position within latitudes at which the EW trending volcano-tectonic structure of the YTVL (Yerer Tullul Wellel Volcano-Tectonic lineament) intersects with the NNE trending fault system of the MERV makes the area an important structural feature $[6,40]$. The area was under intensive volcano-tectonic activities during the quaternary period, characterized by several common features of past and recent volcanos and calderas [39]. This is evident from the observation of vast lava extrusions at the foot of the slope of mountain Fantalle, dots of extensive scoriceous hills in the locality [42], lava flows in the northern part of the lake [43], and the availability of a number of hot springs supplying the lake. A detailed description of the geology of the area can be obtained from other research reports $[6,7,42,43,45]$. 


\section{Methods}

\subsection{Stream Networking and Catchment Delineation}

An accurate and automated determination of a drainage structure of a catchment is extremely crucial for various applications. Band [46] stated that catchment delineation is very important for the study and management of hydrological, geomorphological, landscape, and ecological phenomena [47]. Drainage networks (especially flow directions) are used as an input in a various physical-based hydrological models such as SWAT (Soil And Water Assessment Tool [48]), WEAP (Water Evaluation And Planning), ANSWERS (Areal Nonpoint Source Watershed Environmental Response Simulation) [49], WEPP (Water Erosion Prediction Project), KINEROS (kinematic runoff and erosion model), etc. The available algorithms in GIS can automatically extract the drainage information of a catchment from a digital elevation model (DEM), including flow directions, stream networks, and associated sub-basins [50,51].

In this study, the drainage networking and catchment delineation for Lake Basaka and surrounding areas has been done, which helps us to understand what is happening in the nearby catchments and explain the potential sources/causes of GW flux. The characterization of the lake's catchment (surface and subsurface) and surrounding areas plays a great role in the identification of potential sources. The shape of the Lake Basaka catchment and the contributing area (CA) to the lake water (surface/direct runoff or topographic catchment) was processed from a DEM in ArcGIS 9.2 [52]. Investigations of flow direction, flow accumulation, and catchment delineation were carried out. First, the $90 \mathrm{~m}$ resolution DEM was downloaded from the NASA Shuttle Radar Topography Mission (SRTM) [53]. The DEM resolution was then reduced to $15 \mathrm{~m}$ by a resampling technique. Appropriate pre-processing has been done in ArcGIS such as georeferncing, projecting to known coordinates (UTM), sink filling, and clipping. The DEM was converted to a grid so that each cell has a unique value, from which the flow direction and flow accumulation were calculated using the algorithm available in GIS.

The flow direction was determined by identifying the neighbouring cell according to the eight-pour point concept. A $3 \times 3$ moving window was used to locate the flow direction for each cell. The steepest descent direction from the center cell of the window to one of its eight neighbours was chosen as the flow path. This method is called the D8 (deterministic-eight node) algorithm [54]. D8 is a type of raster data representation [51] and remains the most frequently used method for determining CAs $[54,55]$. It assumes that the drainage divide (usually on ridges) is the line at which the flow accumulation value is zero, and those cells with flow accumulation greater than the threshold value provided by the user are assumed to be streams, channels, or rivers. The flow accumulation (i.e., accumulation of up-slope CA for a given cell) was generated by summing all the up-slope cells draining to it $[56,57]$. The synthetic drainage network was derived by setting a specific threshold value for the contributing pixels on the flow accumulation map. Different contributing pixel (CP) sizes were tested, and the ones covering the different stream flow types (overland, intermittent, and perennial) that were almost similar to the natural drainage network of the area were finally adopted. The shape of the lake was selected as a single pour/outlet point of a stream, and all the cells contributing the flow to that pour point were marked as a catchment. The key assumption here is that the water from a certain cell would flow to the adjacent cell with the steepest relative gradient. The detailed procedure of catchment delineation is described in other reports $[7,46,47,51,55,57]$.

\subsection{Estimation of Groundwater Flux}

GW flux is the most important parameter, sometimes the major component of a lake's water balance $[7,9,27,30,32,57]$. As indicated in the Introduction, various approaches and methods have been developed for the quantification of GW flux, but accurate measurement or quantification of GW flux is the most difficult part of hydrologic studies of lakes involving GW flux $[7,9,30]$, especially for data scarce catchments like that of Lake Basaka. Moreover, each method has its own merits and 
uncertainties. Usually, GW flux is estimated as the net GW inflow ( $G_{\text {net }}=$ inflow - outflow $)[9,41]$ or calculated as the residual error $[7,9,23,30]$.

In this study, GW flux was estimated using the conceptual water balance model developed by others $[7,9]$ for the study area. The conceptual water balance model was already calibrated and validated by Dinka et al. [9] and was found to be performing well within the required performance level. The GW flux estimation was done based on the volume-based (Equation (1)) and depth-based (Equation (2)) procedures [6]. The surface area of the lake was estimated from the rating curve equation (Equations (4) and (5)) developed by Dinka [7] and adopted by Dinka et al. [9].

$$
\begin{gathered}
G_{n e t, t}=\left(H_{t}-H_{t-1}\right) \cdot A_{m, t}-\left(P_{t}-E_{t}\right) A_{m, t}-\left(Q_{t}+Y_{t}\right) \pm \varepsilon_{t} \\
H_{t}=H_{t-1}+\left(P_{t}-E_{t}\right)+\frac{\left(G_{n e t}, t+Q_{t}+Y_{t}\right)}{A_{m, t}} \pm \varepsilon_{t} \\
A_{m, t}=\frac{A_{1, t}+A_{2, t}}{2} \\
A_{1, t}=-0.0629 H_{t-1}^{4}+0.86 H_{t-1}^{3}+3.8353 H_{t-1}^{2}+14.033 H_{t-1}-0.8939 \\
A_{2, t}=-0.0629 H_{t}^{4}+0.86 H_{t}^{3}+3.8353 H_{t}^{2}+14.033 H_{t}-0.8939
\end{gathered}
$$

where $H$ is the lake stage (m), $G_{\text {net }}$ is the net GW flux (inflow - outflow) $\left(\mathrm{m}^{3}\right), P$ is the precipitation falling directly on the lake surface $(m), E$ is the lake evaporation $(m), Q$ is the surface runoff $\left(\mathrm{m}^{3}\right), Y$ is the sediment volume delivered to the lake from its catchment by erosion $\left(\mathrm{m}^{3}\right), A$ is the surface area of the lake at the beginning $\left(A_{1}\right)$ and at the end $\left(A_{2}\right)$ of the month, $t$ is the current time, $t-1$ is the previous time, and $\varepsilon$ is the error term.

Each of the water balance components are computed systematically as per the method presented by Dinka et al. [9]. The results obtained for the GW flux in this study were compared with the previously reported values for the area by other researchers in different time periods. The sources of GW flux to the lake were discussed in relation to these study results, previous findings, and the literature. Finally, the potential sources of GW flux are suggested and recommendations are made for the sustainable management of the lake water. Perhaps an attempt was made to support most of the discussions by referring to published reports in the area and elsewhere in the world.

\section{Results and Discussion}

\subsection{Catchment Drainage Structure}

The results of automatically generated drainage networks for Lake Basaka (flow direction, accumulation, stream network, and sub-catchments) are shown in Figures 4 and 5. The flow accumulation map (Figure 4a) clearly indicates the contributing pixels (CPs) in the range of 0 to 17,900 . Figure $4 \mathrm{~b}$ shows the synthetic drainage network derived from flow accumulation by setting a threshold number for the CPs. Three stream flows have been identified for the area (Figure $4 \mathrm{~b}$ and Figure 5): stream 1 (initiation of overland flow), stream 2 (intermittent flow), and stream 3 (perennial flow). The initiation of overland flow was captured by $100 \mathrm{CPs}$; whereas the intermittent (surface runoff) flows are covered by CPs in the range of 1000 to 6000. The perennial (River Awash) flow is captured at $17,000 \mathrm{CPs}$. For the lake catchment, stream 1 (initiation of overland flow) and stream 2 (surface runoff) are clearly captured within a CP range of 100 to 6000 . As is evident from Figures 4 and 5, two major streams (surface runoff) are flowing to the lake during rainfall events; one is coming from the north part of the catchment (sub-basin 1) and entering to the lake in the northwest side, whereas the other stream is coming from the South and Southwest (sub-basin 2) and entering the lake in the southern side. These two flows have almost equal CA; hence approximately equal magnitudes of surface runoff are expected. 
Figure $4 \mathrm{c}, \mathrm{d}$ presents the sub-catchments contributing to Lake Basaka. The lake catchment can be generally divided into four sub-catchments (two big and two small) depending upon the stream flows (Figure 4c). However, the major sub-watershed can be generally divided into two sub-catchments considering the pixel size of 1000 as the threshold value (Figure $4 \mathrm{~d}$ ), since the other two are characterized by overland flows only (see Figure $4 \mathrm{~b}$ ) and have a very flat slopes $(<5 \%)$. Accordingly, the effective CA for runoff and soil loss to the lake water is only $380 \mathrm{~km}^{2}$ out of the total catchment area of $500 \mathrm{~km}^{2}$.
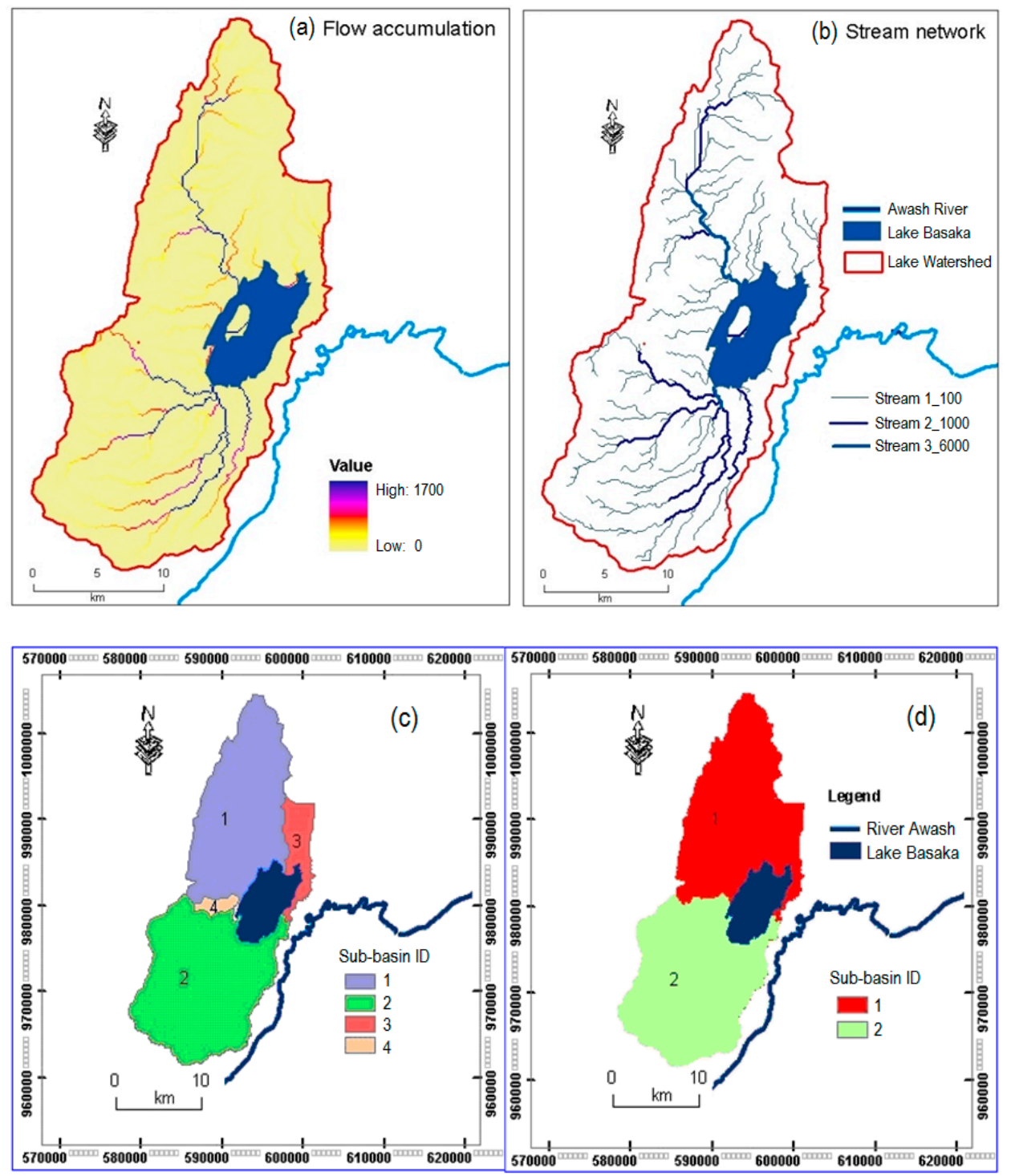

Figure 4. (a) Flow accumulation, (b) stream network, and (c,d) sub-catchments delineated for the Lake Basak catchment. (Note that the shape of Lake Basaka is that of 2008).

Figure 5 shows the synthetically generated drainage network for the Lake Basaka catchment and its surrounding areas. Evidently, the synthetically generated perennial flow obtained from the DEM almost matches the actual Awash River flow pattern. The good agreement obtained between the generated stream network from DEM and the actual drainage network of the area is an indicator of the good preprocessing (e.g., projecting, georeferencing, sink filling) and processing (choice of algorithms, computation of flow direction and accumulation, and the extraction of the drainage network) of DEM in GIS. The different types of flows are captured very well when assigning threshold numbers of CPs. 


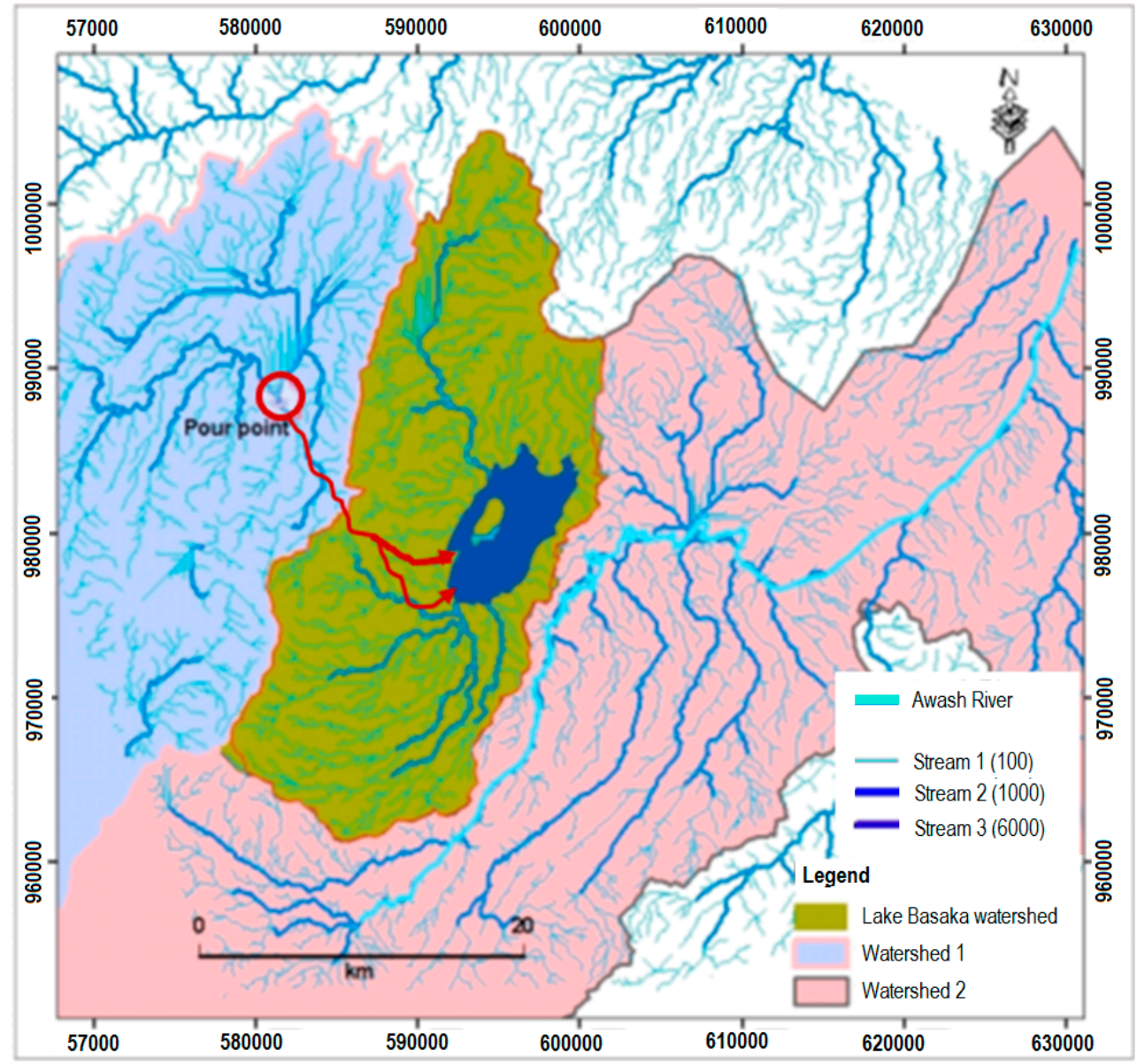

Figure 5. Watershed delineated for the Lake Basaka catchment, the surrounding showing drainage/stream network pattern, and the recharge zone in the northwest side of the lake. (Note that the red line shows the suggested direction of subsurface contribution to the lake).

\subsection{Dynamics of Groundwater Flux}

The seasonal, annual, and decadal fluxes for Lake Basaka at different hydrologic periods of interest are illustrated in Figures 6 and 7. Figure 6 shows the seasonal and decadal fluxes, whereas Figure 7 shows the annual fluxes. As is evident from Figure 6, the net GW fluxes are positive (inflow > outflow) for most of the months in all the years considered. The net GW flux shows variability both seasonally and annually, but the annual variability is significant compared to the seasonal variability. However, the net GW flux into the lake is not showing significant fluctuation within the same season in all the periods considered. This could be due to the fact that there are a number of hot springs flowing into the lake throughout the season along a western and south-western edge of the lake (see the red arrows in Figure 5). The other possible reason, as also suggested by others [6,7], could be the flow of GW towards the lake (especially during dry periods) from the surrounding GW aquifer systems, depending upon the potential head difference at the interface of the two hydrologic systems.

Lake Basaka showed great fluctuations (size and shape) (Figure 1a) throughout its historical record and simulated periods [7-10]. A small rise in lake level resulted in the inundation of greater surface area and volume [8]. Evidently, the fluxes of E, $\mathrm{P}$, and $\mathrm{G}_{\text {net }}$ are showing an increasing annual and decadal trend as the function of the continuous increment of the lake level (Figure 7). It should be noted that years receiving low rainfall (dry period) are characterized by relatively higher $G_{\text {net }}$, and vice versa. This is due to the fact that rainfall is the governing factor for the other water balance components $(Q, Y)$ and/or even the $G_{n e t}$ itself. It can be seen from Figure 6 that the seasonal fluctuation of $Q$ and 
$\mathrm{Y}$ fluxes are a function of $\mathrm{P}$ flux, which is mostly influenced by the seasonal migration of monsoon winds. Since the study area is located in the tropics with a semi-arid climate, the rainfall pattern of the area is mostly the effect of ITCZ (see Section 2.2).

Lake E, as a major ( $93 \%)$ outflow component, showed a continuous annual and decadal increment, depending upon the surface areal expansion of the lake, but, it showed slight seasonal variation (Figure 6) depending upon the seasonal climate of the area. It has its highest value during the driest period, when temperature is relatively high and $\mathrm{RH}$ is relatively low, and declines during the main rainy season (especially August and September). GW flux, as the major ( $56 \%$ post-2000s) inflow component, showed a proportional annual and decadal increment to compensate the continuously increasing E flux as a function of lake expansion. It also showed significant inter-decadal fluctuations (Figures 6 and 7): 1.45, 2.11, 3.33, and $4.83 \mathrm{M} \mathrm{m}^{3}$ /Month, respectively for the 1970s, 1980s, 1990s, and 2000s. Here, it is important to note that $\mathrm{G}$ flux remains relatively constant within the same season but showed significant inter-seasonal variability (Figure 7). Belay [6] also reported the same general trend of GW flux for Lake Basaka.

The seasonal and decadal net GW fluxes for the various periods are illustrated in Figure 8. The obtained GW inflow for the period between 1960 and 1972 is about $0.05 \mathrm{~m}^{3} / \mathrm{s}$, which accounts for about $16 \%$ of the total inflow. There was no GW outflow during that the same period. The obtained net GW flux for the period between 1960 and 1972 in this study $\left(0.05 \mathrm{~m}^{3} / \mathrm{s}\right)$ is in a good agreement with that of Halcrow [43]. The net GW flux obtained from the model $\left(0.48 \mathrm{~m}^{3} / \mathrm{s}\right)$ in this study for the 1970s is almost 10-fold compared to the 1960s, which indicates the possibility of subsurface sources, other than hot springs, contributing into the lake. The discharge from hot springs in the 1970s was about $0.05 \mathrm{~m}^{3} / \mathrm{s}$ [43]. The net GW flux increased to about $46 \%$ of the total inflow in the $1970 \mathrm{~s}$. It is important to note that the errors in the estimation of individual water balance components are different for the different studies. For example, the E flux estimated by Belay [6] is about $62 \mathrm{Mm}^{3}$, which is slightly different from this study's result $\left(59 \mathrm{Mm}^{3}\right)$. However, most of the previous reports $[6,14]$ used the long-term average values of water balance components. This study considered the variation of the lake fluxes during different hydrologic periods; thus the result is more acceptable. Tessema [11] estimated the discharge from the hot springs to be equal to $1.2 \mathrm{~m}^{3} / \mathrm{s}$, which is almost in agreement with the net GW flux obtained $\left(1.13 \mathrm{~m}^{3} / \mathrm{s}\right)$ in this work for the 1990s. According to Tessema's [11] report, there is no other sub-surface source (except spring water) flowing into Lake Basaka.

On the other hand, this study's results do not agree with the estimated result obtained by Goerner et al. [16], who estimated that the discharge of the hot springs (main GW flux) was about $0.05 \mathrm{~m}^{3} / \mathrm{s}$ in 1998 . However, most of the hot springs were submerged during their time of measurement; hence their reported result can not be a representative value for the discharge to the lake from hot springs. Even the same study [16] indicated, from water balance calculations, that at least $1.59 \mathrm{~m}^{3} / \mathrm{s}$ of water (1998 average) must flow into the lake to compensate for $\mathrm{E}$ loss and allow the water to level rise $\left(8 \%\right.$ of the $\left.1.59 \mathrm{~m}^{3} / \mathrm{s}\right)$. The estimated GW flux for the same period $(2000 \mathrm{~s})$ in this study $\left(1.6 \mathrm{~m}^{3} / \mathrm{s}\right)$ is in a good agreement with their result. This condition clearly indicates the possibility that subsurface sources other than the hot springs flow to the lake.

Figure 8 also presents the percentage contributions of GW to the lake in different hydrologic periods. The percentage contribution of GW flux estimated in this study is highly variable, which is in the range of $16 \%$ to $56 \%$, depending upon the different hydrologic years considered. Most study reports $[3,6,14]$ indicated that the GW contribution to the lake is about $50 \%$, and the result obtained in this study is almost comparable to the previous results for the 1990s and 2000s, during which most of the reports were done. In general, all the previous reports and current study results have indicated that GW flux is the major inflow component of the lake's water balance; hence GW plays a leading role in the hydrodynamics and existence of Lake Basaka. 


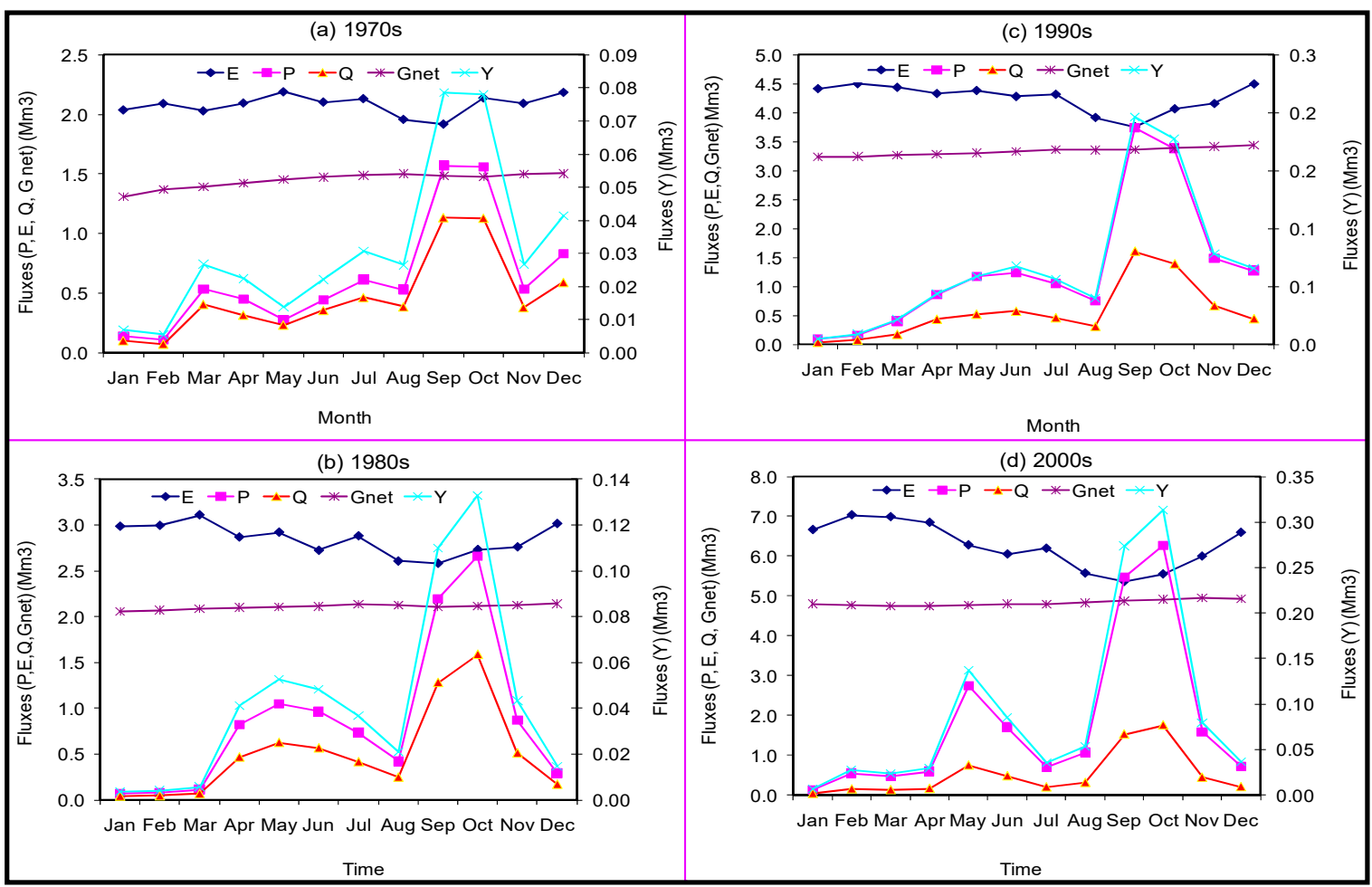

Figure 6. Seasonal and annual fluxes for Lake Basaka per decade: (a) 1970s, (b) 1980s, (c) 1990s, (d) $2000 \mathrm{~s}$.

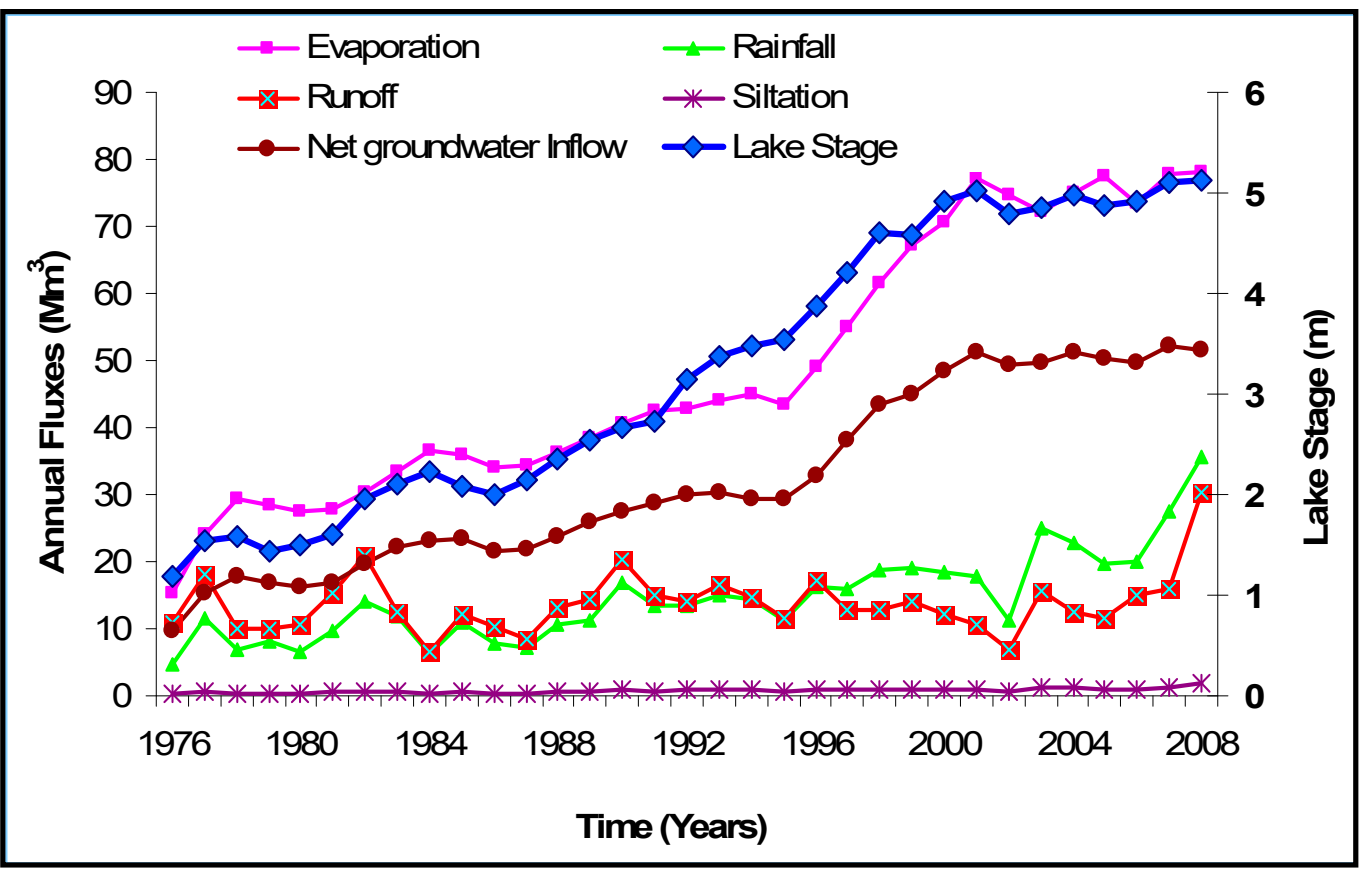

Figure 7. Annual fluxes and simulated lake stage for Lake Basaka (1976 to 2008) [7,9]. 


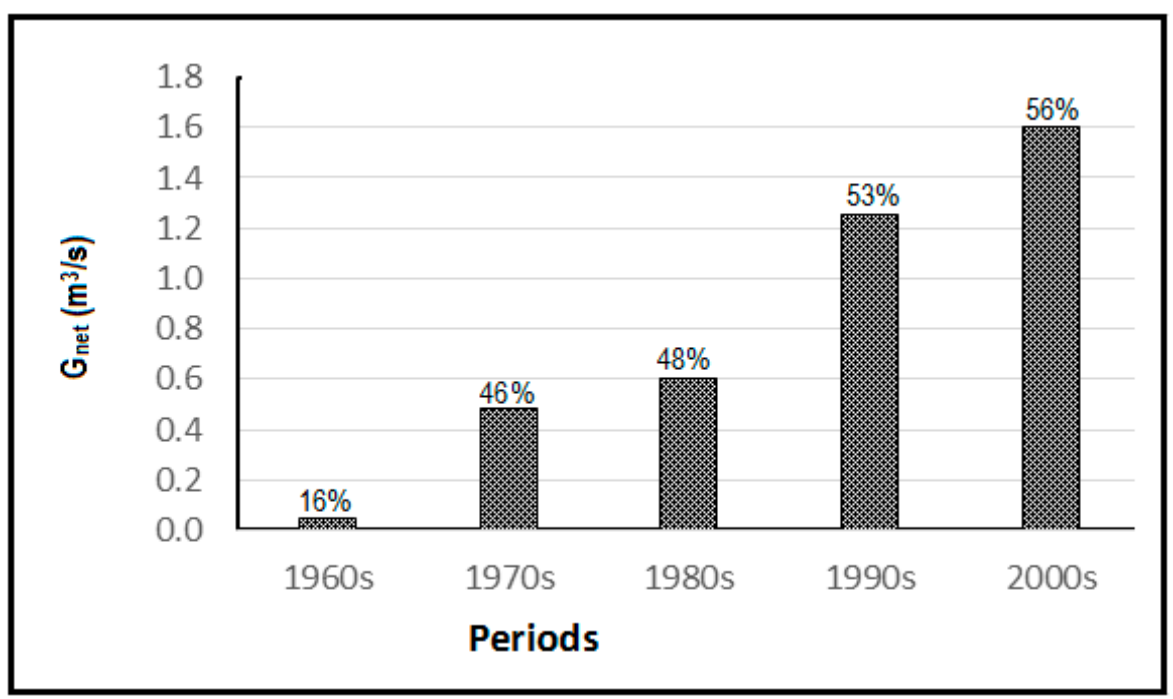

Figure 8. Decadal net Groundwater flux to Lake Basaka.

\subsection{Potential Sources/Causes of Groundwater Flux}

This study result and other reports $[2,5,7,9,14]$ clearly indicated that GW flux is the main component responsible for the hydrodynamics and existence of Lake Basaka and, hence, responsible for its expansion. As mentioned earlier, the root cause/source of the increment of the GW flux into the lake is not fully identified. There are different views and suggestions by different scholars. The various views are summarized as follows:

1. Increment of recharge from the nearby irrigation schemes (Abadir and Nura-Erra farms) $[3,5,8,14]$. Dinka [8] generally indicated that the establishment of large scale irrigation schemes within the lake's catchment have contributed to the lake's expansion directly or indirectly. The study also mentioned the speculations related to the effect of the recently (post 2008) established Fantalle irrigation project. The rationale for the suggestion about the Fantalle project is due to the fact that significant quantities of water $\left(18 \mathrm{~m}^{3} / \mathrm{s}\right)$ are diverted from the Awash River and are recharging the lake catchment at its upstream side, excess irrigation water is discharged to the lake directly, and the irrigation project disturbs the natural drainage patterns of the area [8].

2. Water transmission loss from Awash River because of its increased water level after the construction of Koka Dam, located some $152 \mathrm{~km}$ upstream [2,5,14]. The water losses and recharges, according to Ayenew et al. [5], are facilitated by the presence of active terminal faults in the region [7], favorable geologic factors, and the availability of water.

3. Increased recharge from the submerged hot springs [12-15]. However, these studies did not mention the cause for the increase of hot springs. Klemperer and Cash [15] suggested that the possible cause could be hot springs after analysing the 1973 chemical analysis data in the United Nations report [58].

4. The interconnection of groundwater of eastern Africa [38,41] and the interconnection of East African rift valley lakes $[4,8]$, which are facilitated by the presence of active faults.

5. Lake neotectonisim $[4,8,11,16,39]$. Neo-tectonic activities, as suggested by Goerner et al. [16], have modified the structure of the basin and triggered the growth of the lake [6]. Ayenew and Becht [4] reported that there are strong signs of changes in the hydrological settings of the rift system by neotectonism (earthquakes and volcanic eruption). They concluded, from a water balance study, that the GW flow in the rift is controlled by geologic structures, either via flows in the tensional faults or through fluvial and lacustrine deposits, the occurrence of which is influenced by tectonism. 
The subsurface contribution from Awash River through leakage is not as convincing and justifiable. The construction of Koka Dam was completed in 1960, while significant GW flux and lake expansion was started in the 1990s. Of course, a certain amount of water leakage/seepage is expected from the Awash River. The existence of significant transmission loss from the Awash River should be verified by an independent study. Moreover, the suggested interconnection of the groundwater of eastern Africa and the interconnection among EARV lakes are not verified by an independent investigation and require due attention. The author supports the suggestion related to lake neotectnonism as the cause for the increased GW flux, which is also supported by many independent researchers $[4,8,11,16,39]$.

In addition to lake neotectonism, the author of this study also supports the recharge from upstream irrigation schemes (MSE, Nura-Era, and Fantalle) as the cause for the increment of GW flux. The water balance study made by Dinka [7] indicates the existence of an interaction between the lake and groundwater system of the area. MSE has been using an uncontrolled furrow irrigation system for many years (since 1969). Water is also stored in Night Storage Reservoirs (NSR), which are unlined and filled with siltation. The irrigation and drainage canals are also not lined. Hence, significant seepage loss is expected from the NSR and the irrigation and drainage canals. In general, irrigation and drainage water management at MSE is very poor $[7,59]$. The infield water application performance evaluation made by Dilsebo [60] showed that the actual field application efficiency is in the range of $12 \%$ to $70 \%$. He emphasized the possibility of achieving an application efficiency of about $75 \%$ with better water management. Similarly, even the worst irrigation water management is expected in the other irrigation schemes in the region, i.e., Nura-Era and Fantalle. However, it is difficult to conclude that the Fantalle project has significant sub-surface contribution to the lake since the project was under a developmental stage until 2010 and the significant GW flux to the lake started before that time. The effect of the Fantalle irrigation project has to be justified or verified scientifically and requires due attention.

Furthermore, this study would like to bring to attention the issue of significant sub-surface contribution from the western side of the lake, outside of the lake's surface catchment. This watershed is probably the main cause/source of GW flux to the lake. This suggestion is based on the result of the drainage networking (Figure 5) presented earlier in this study. The figure indicated that the drainage basin at the west side of the lake catchment (watershed 1) has no surface outlet, but showed one concentration (pour) point (shaded by red) with no lake or river. Runoff from watershed 1 is concentrated at this pour point, thereby recharging the aquifer. Hence, an increment of water yield from the catchment could be expected. It is possible to suggest that watershed 1 is probably the principal sub-surface water CA to the lake. This suggestion is based on the following main reasons: (i) the very big size (surface area) of watershed 1 (Figure 5) and (ii) the recharging mechanism and GW flow pattern of the region (Figure 9), suggested by Ayenew et al. [5]. The GW contribution from the pour point of watershed 1 to the lake is indicated by the red line arrow shown on Figure 5 . There could be a probability that these two surface runoff catchments have underground connectivity by certain changes and, hence, could be considered as part of the lake's groundwater or sub-surface catchment. Probably, these two subsurface watersheds were separate in previous times but were recently combined (mid-1990s) due to the effect of terminal faults created by the rift system's influence. Ayenew et al. [5] reported that the presence of active terminal faults in the region facilitated the groundwater recharge. According to local information (informal communication in 2010), a big fault was created in 1996 in the southwestern side of the lake, and a big, noisy water flow to the lake has been occurring within the fault. The faults are now closed, and it is difficult to see the sub-surface flow to the lake. The significant GW contribution (Figure 7) started after the mid-1990s. Before being submerged, the hot springs flowing to the lake were in the southwest direction; thus the suggestion seems ideal and logical. Other independent studies [3,6] also suggested that about $64 \%$ of the GW contribution to the lake comes from the western side of the lake. However, the previous authors did not mention the potential causes and means of contribution. 


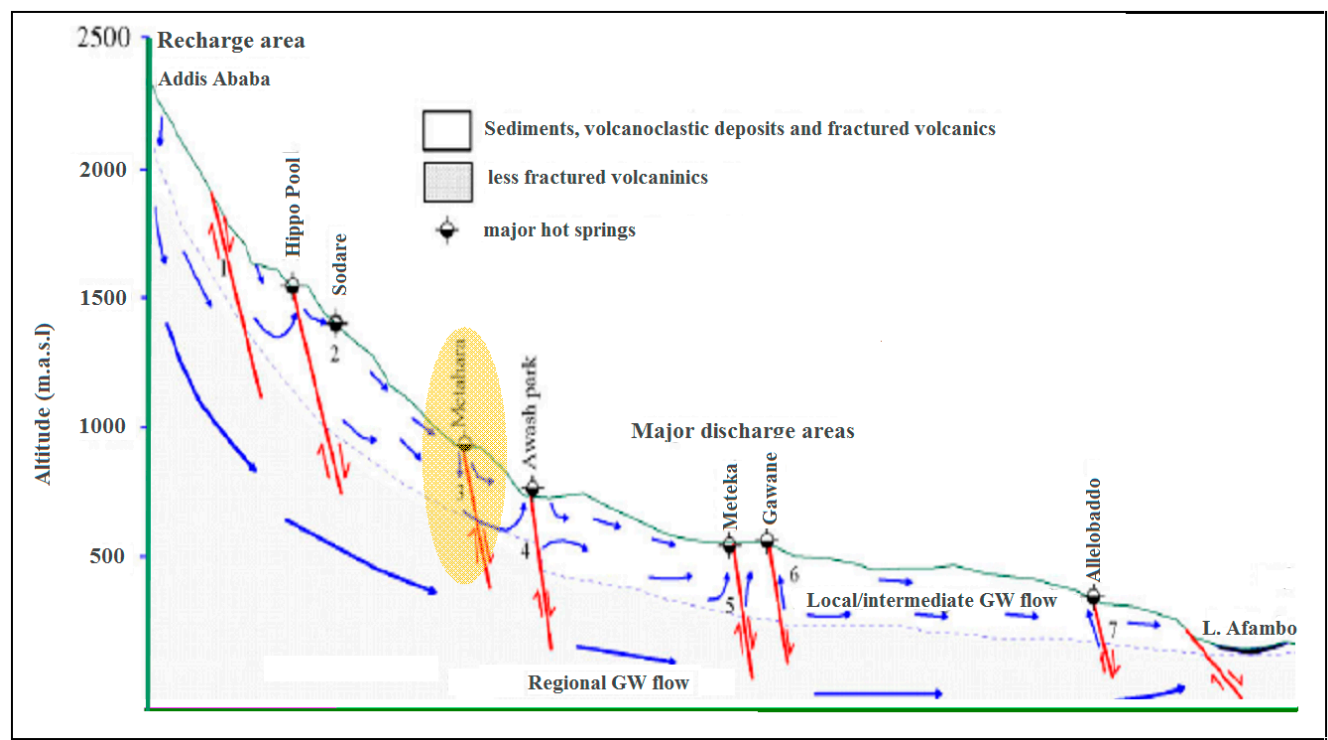

Figure 9. Schematic graph illustrating the recharge and discharge areas, the highland-rift-groundwater (GW) flow, and the fault controlled major springs section, showing the recharge areas and the GW flow pattern of Awash basin (Modified from [5]). (Note that the shaded area is the Matahara area, including Lake Basaka).

In addition to the above possible reasons, there are also speculations about the subsurface flow of water from very far distances (like Red Sea) due to rift system influences. This suggestion further strengthens the possibility of subsurface sources other than hot springs, suggested earlier under Section 4.2. Recent studies $[7,8]$ are suggesting the possibility of rift system influence on the lake because of its strategic location in the active parts of the MER. Changes are happening within the MER in particular and GEARV in general. The hydrochemical source identification made by Dinka [18] also justifies the above argument. The study clearly indicated that the lake water has similar hydrochemcial facis with that of the hot springs; both waters have a changing hydrochemical facies and paths of evolution. The study concluded that these waters have a chemical composition almost similar to that of seawater, stayed for a very long period of time in the hydrologic cycle, and originated in areas very far distances away. The author of this study would like to suggest the possibility that the seawater is preparing its way underground. The Red Sea is believed to be dividing the African continent into two sub-plates: the Nubian sub-plate and the Somalian/Arabian sub-plate [6,7]. Based on a visit to the Danakil Depression area in 2005, one online reporter for a German website [61] indicated that the Afar Triangle (where the three sub-plates meet) is moving apart at a staggering speed, more rapidly than the expected geologic time-scale, preparing its way for the red-sea to flow through the rift valley and create an ocean, forcing Africa to lose its horn. The other very interesting information related to the above suggestion is the very shallow groundwater condition in the Matahara plain area, including the Matahara sugarcane planation. The groundwater of the area is very shallow, in the range of 0.5 to $2 \mathrm{~m}$ below ground level [9], and its chemical characteristics are more similar to those of the hot springs and Lake Basaka than that of the Awash River [18]. However, the effect of the Red Sea on Lake Basaka and the Matahara region is not scientifically proven and requires due attention.

\section{Conclusions and Recommendations}

The drainage networking result showed the good agreement between the actual patterns of the Awash River flow and the synthetically generated perennial flow obtained from the DEM. The automatically generated network captured the meandering of the Awash River very well. The different types of stream flows (overland flow, intermittent flow, and perennial flow) were captured very well while assigning threshold numbers of CPs. The good agreement between the synthetically 
generated flow from the DEM and the actual river flow is an indicator of the good preprocessing and processing ability of DEM in GIS.

The water balance analysis result indicated that the major fluxes $\left(E, P, G_{n e t}\right)$ are showing an increasing annual and decadal trend as a function of the continuous increment of the lake level and surface area. Lake $\mathrm{E}$ and $\mathrm{G}_{\text {net }}$ are the major lake fluxes accounting for (post-2000s) about $93 \%$ and $56 \%$ of the outflow and inflow components of the lake's water balance, respectively. Hence, GW is mostly responsible for the existence and fluctuation of the lake. The GW flux showed a continuous annual and decadal increment to compensate for the $\mathrm{E}$ flux in different time periods. It showed significant inter-decadal increment from $0.05 \mathrm{~m}^{3} / \mathrm{s}(16 \%)$ in the $1960 \mathrm{~s}$ to about $1.6 \mathrm{~m}^{3} / \mathrm{s}(56 \%)$ in the 2000s. The trend of GW flux is not the same in different periods. The significant increase of GW flux was observed after the mid-1990s, which coincides with the period of significant lake level rise in the area. The increment of net GW flux by 10 -fold from the $1960 \mathrm{~s}\left(0.05 \mathrm{~m}^{3} / \mathrm{s}\right)$ to the $1970 \mathrm{~s}\left(0.48 \mathrm{~m}^{3} / \mathrm{s}\right)$ indicates the possibility of subsurface sources other than the hot springs contributing to the lake.

The actual cause/sources of the increment of the GW flux into the lake are not yet fully understood. As discussed earlier in detail (Section 4.3), there are different views and suggestions about the possible sources/causes of GW flux to Lake Basaka. The likely causes of the increase of GW flux to the lake could be due to one or a combination of the following reasons: (i) an increase of GW recharge from irrigation schemes (Matahara Sugar Estate, Nura-Era Farm, Fantalle Irrigation Project), which is facilitated by the presence of active terminal faults and the unstable geologic condition of the area; (ii) lake neotectonism (earthquakes and volcanic eruption), which is continuously affecting the geologic structure and geological setting of rift systems; (iii) subsurface flow from a nearby surface catchment located on the western side of the lake; and/or (iv) rift system influence on GEARV. According to this study, the contribution from the nearby catchment is the main source/cause of GW flux, followed by the recharge from the nearby irrigation schemes. The suggestion related to the moving apart of the great EARV as a preparation for the Red Sea to create a new ocean by cutting the Horn of Africa remains valid. The Red Sea might have already started flowing within the deep aquifer of the GEARV region, particularly affecting Lake Basaka and the Matahara region due to its topography and strategic location. This suggestion is not scientifically proven and, hence, requires due attention.

Owing to the poor water quality (high salinity and alkalinity) of the lake, there is negligible or no benefit obtained from the lake compared to its damaging effects. The continuous increment of GW flux and the dramatic expansion of the lake, with no doubt, is a great developmental challenge in the region. The author of this article shares the above-stated reasons as the potential sources/causes of GW flux directly or indirectly. This study does not fully explain and justify the exact causes for the increment of the GW flux to the lake. Some of the suggestions are based on certain scientific assumptions and require verification by an independent study. Therefore, the author of this article would like to suggest a comprehensive and detailed investigation to determine the potential source/causes. An integrated and independent investigation is highly recommended, which requires a multi-disciplinary approach comprised of geologists, hydrologists, hydrogeologists, meteorologists, soil scientists, soil and water conservationists, etc. A study that considers all the parameters related to GW flux and the interaction of the lake with the GW system of the area is highly encouraged.

The following specific future actions are suggested by the author:

(1) Accurate quantification of the lake's evaporation using different approaches.

(2) Understanding the interconnection between the groundwaters and the lakes of the rift valley region.

(3) Delineation and morphometric analysis of the lake catchment. In line with this, accurate quantification and characterization of streamflow and erosion is very crucial.

(4) Delineating the aquifers contributing to GW flux to the lake and describing their physical characteristics is very crucial. This requires the characterization of the bed-rock and quaternary aquifers of the lake catchment (surface and sub-surface) and the surrounding areas and GW throughflow. 
(5) Accurate quantification and characterization of GW flux using various approaches such as the physical based hydrologic models (e.g., MODFLOW). This, in turn, requires the characterization of the geohydrology of the region for a better and reliable understanding of the conceptual model of the aquifer system, including processes such as geological mapping, aquifer delineation and characterization, etc. It also requires digging observation wells and/or the installation of GW monitoring piezometers at representative sites within the lake's catchment and surrounding areas. The quantification and geohydrochemcial characterization of the GW flux will help when the mapping of GW depth and quality and their flow directions and patterns.

Give more emphasis to catchment management measures for a sustainable lake management strategy, which will be facilitated by the morphometric analysis and aquifer characterization suggested under actions (3) and (4). Accordingly, any of the combination of the following measures are recommended: (i) the diversion of surface runoff to the Awash River, (ii) pumping out water accumulated at the pour point of watershed 1 located on the western side of the lake catchment, (iii) devising a means to increase the lake's evaporation, (iv) mixing the lake water with the Awash River with proper treatment, (v) desalinating the lake water and using it for different purposes (irrigation, domestic, industry, energy production), and/or (vi) improving the vegetation cover of the lake catchment.

Acknowledgments: The author thanks the Ethiopian Sugar Development Agent (currently called the Ethiopian Sugar Corporation), specifically the Metehara Breading Station of the Research Directorates, for their support during data collection. He is also thankful to the NRF (National Research Foundation) for proving financial support during the writing of the paper.

Author Contributions: All parts of the article are the work of the author. The initiation of the research, data collection, analysis, interpretation, and article write-up were done by the author.

Conflicts of Interest: I declare that there are no conflicts of interest in this article. The article belongs to the author only.

\section{References}

1. Gasse, F. Hydrological changes in the African tropics since the Last Glacial Maximum. Quat. Sci. Rev. 2000, 19, 189-211. [CrossRef]

2. Ayenew, T. Environmental implications of changes in the levels of lakes in the Ethiopian rift since 1970. Reg. Environ. Chang. 2004, 4, 192-204. [CrossRef]

3. Ayenew, T. Water management problems in the Ethiopian rift: Challenges for development. J. Afr. Earth Sci. 2007, 48, 222-236. [CrossRef]

4. Ayenew, T.; Becht, R. Comparative assessment of water balance and hydrology of selected Ethiopian and Kenyan Rift Lakes. Lakes Reserv. Res. Manag. 2008, 13, 181-196. [CrossRef]

5. Ayenew, T.; Kebede, S.; Alemyahu, T. Environmental isotopes and hydrochemical study applied to surface water and groundwater interaction in the Awash River basin. Hydrol. Process. 2007, 22, 1548-1563. [CrossRef]

6. Belay, A.E. Growing Lake with Growing Problems: Integrated Hydrogeological Investigation on Lake Beseka, Ethiopia. Ph.D. Thesis, Universitäat Bonn, Bonn, Germany, 2009.

7. Dinka, M.O. Analyzing the Extents of Basaka Lake Expansion and Soil and Water Quality Status of Matahara Irrigation Scheme, Awash Basin (Ethiopia). Ph.D. Thesis, BOKU University, Vienna, Austria, May 2010.

8. Dinka, M.O. Analysing the extents (size and shape) of Lake Basaka Expansion (Main Ethiopian Rift Valley) using Remote Sensing and GIS. Lake Reserv. Res. Manag. 2012, 17, 131-141. [CrossRef]

9. Dinka, M.O.; Loiskandl, W.; Ndambuki, J.M. Hydrochemical modelling for Lake Basaka: Development and application of a conceptual water budget model. Environ. Monit. Assess. 2014, 186, 5365-5379. [CrossRef] [PubMed]

10. Dinka, M.O. Lake Basaka Expansion: Challenges for the Sustainability of the Matahara Irrigation Scheme, Awash River Basin (Ethiopia). Irrig. Drain. 2017. [CrossRef]

11. Tessema, Z. Hydrochemical and Water Balance Approach in the Study of High Water Level Rise of Lake Beseka. Master's Thesis, University of Birmingham, Birmingham, UK, 1998. 
12. Zemedagegnehu, E.; Travi, Y.; Aggarwal, P. Application of environmental isotopes to determine the cause of rising water levels in Lake Beseka, Ethiopia. In Isotope Techniques in Water Resources, Development and Management, Proceedings of the International Symposium on Isotope Techniques in Water Resources Development and Management, Vienna, Austria, 10-14 May 1999; International Atomic Energy Agency: Vienna, Austria, 1999.

13. Abebe, G. Feasibility Study on the Proposed Remedial Measures of the Lake Beseka Level Rise. Master's Thesis, Alemaya University, Haramaya, Ethiopia, September 2000.

14. Alemayehu, T.; Ayenew, T.; Kebede, S. Hydrochemical and Lake level changes in the Ethiopian Rift. J. Hydrol. 2006, 316, 290-300. [CrossRef]

15. Klemperer, S.L.; Cash, M.D. Temporal geochemical variation in Ethiopian Lakes Shala, Arenguade, Awasa, and Beseka: Possible environmental impacts from underwater and borehole detonations. J. Afr. Earth Sci. 2007, 48, 174-198. [CrossRef]

16. Goerner, A.; Jolie, E.; Gloaguen, R. Non-climatic growth of the saline Lake Beseka, Main Ethiopian Rift. J. Arid Environ. 2009, 73, 287-295. [CrossRef]

17. Dinka, M.O.; Loiskandl, W.; Ndambuki, J.M. Hydrochemical characterization of various surface water and groundwater resources available in Matahara areas, Fantalle Woreda of Oromiya Region. J. Hydrol. Reg. Stud. 2015, 3, 444-456. [CrossRef]

18. Dinka, M.O. Delineate the Hydrochemical Composition and Origin of Various Surface Water and Groundwater Resources in Matahara Area (Ethiopia). Inland Waters 2017, in print. [CrossRef]

19. Elias, E. Pastoralists in Southern Ethiopia: Dispossession, Access to Resources and Dialogue with Policy Makers; DCG Report No. 53; Dryland Coordination Group: Oslo, Norway, 2008.

20. Gebre, A. Pasoralism under Pressure: Land Alienation and Pastoral Transformations among the Karayyuu of Eastern Ethiopia, 1941 to Present; Shaker Publishing: Maastrich, The Netherlands, 2009.

21. Winter, T.C.; Harvey, J.W.; Franke, O.L.; Alley, W.M. Groundwater and Surface Water a Single Resource; US. Geological Survey Circular 1139; DIANE Publishing Inc.: Denver, CO, USA, 1998; p. 87.

22. LaBaugh, J.W.; Winter, T.C.; Rosenberry, D.O.; Schuster, P.F.; Reddy, M.M.; Aiken, G.R. Hydrological and chemical estimates of the water balance of a closed-basin lake in north central Minnesota. Water Resour. Res. 1997, 33, 2799-2812. [CrossRef]

23. Kalbus, E.; Reinstorf, F.; Schirmer, M. Measuring methods for groundwater-surface water interactions: A review. Hydrol. Earth Syst. Sci. 2006, 10, 873-887. [CrossRef]

24. Rosenberry, D.O.; LaBaugh, J.W.; Hunt, R.J. Use of monitoring wells, portable piezometers, and seepage meters to quantify flow between surface water and ground water. In Field Techniques for Estimating Water Fluxes between Surface Water and Ground Water; Rosenberry, D.O., LaBaugh, J.W., Eds.; U.S. Geol. Surv. Tech. Methods, 4-D2; U.S. Geological Survey: Reston, VA, USA, 2008; pp. 39-70.

25. Merritt, M.L.; Konikow, L.F. Documentation of a Computer Program to Simulate Lake-Aquifer Interaction Using the MODFLOW Ground-Water Flow Model and the MOC3D Solute-Transport Model; US Department of the Interior, US Geological Survey: Reston, VA, USA, 2000; Volume 4167, p. 146.

26. Stets, E.G.; Winter, T.C.; Rosenberry, D.O.; Striegl, R.G. Quantification of surface water and groundwater flows to open- and closed-basin lakes in a headwaters watershed using a descriptive oxygen stable isotope model. Water Resour. Res. 2010, 46. [CrossRef]

27. Yihdego, Y.; Becht, R. Simulation of lake-aquifer interaction at Lake Naivasha, Kenya using a three-dimensional flow model with the high conductivity technique and a DEM with bathymetry. J. Hydrol. 2013, 503, 111-122. [CrossRef]

28. Becker, M.W.; Georgian, T.; Ambrose, H.; Siniscalchi, J.; Fredrick, K. Estimating flow and flux of ground water discharge using water temperature and velocity. J. Hydrol. 2004, 296, 221-233. [CrossRef]

29. Schmidt, C.; Bayer-Raich, M.; Schirmer, M. Characterization of spatial heterogeneity of groundwater-stream water interactions using multiple depth streambed temperature measurements at the reach scale. Hydrol. Earth Syst. Sci. 2006, 10, 849-859. [CrossRef]

30. Ito, I.; Momii, K.; Nakagawa, K. Modeling the water budget in a deep caldera lake and its hydrologic assessment: Lake Ikeda, Japan. Agric. Water Manag. 2009, 96, 35-42. [CrossRef]

31. Awulachew, S.B. Modelling natural conditions and impacts of consumptive use and sedimentation of Lake Abaya and Lake Chamo, Ethiopia. Lakes Reserv. Res. Manag. 2006, 11, 73-82. [CrossRef]

32. Yihdego, Y.; Webb, J.A.; Leahy, P. Modelling of water and salt balances in a deep, groundwater-throughflow lake- Lake Purrumbete southeastern Australia. Hydrol. Sci. J. 2016, 6, 186-199. [CrossRef] 
33. Sacks, L.A.; Swancar, A.; Lee, T.M. Estimating Ground-Water Exchange with Lakes Using Water-Budget and Chemical Mass-Balance Approaches for Ten Lakes in Ridge Areas of Polk and Highlands Counties, Florida; WRI 1998; US Department of the Interior, US Geological Survey: Reston, VA, USA, 1998; pp. 98-4133.

34. Gibson, J.J.; Edwar, T.W.D. Regional water balance trends and evaporation-transpiration partitioning from a stable isotope survey of lakes in northern Canada. Glob. Biogeochem. Cycles 2002, 16, 1-9. [CrossRef]

35. Langston, R.; Hayashi, M.; Roy, J.W. Quantifying groundwater-surface water interactions in a proglacial moraine using heat and solute tracers. Water Res. Res. 2013, 49, 5411-5426. [CrossRef]

36. Kluge, T.; Ilmberger, J.; von Rohden, C.; Aeschbach-Hertig, W. Tracing and quantifying groundwater inflow into lakes using a simple method for radon-222 analysis. Hydrol. Earth Syst. Sci. 2007, 11, 1621-1631. [CrossRef]

37. WWDCE (Water Works and Construction Enterprise). Study of Lake Beseka (Main Report 1); MoWR: Addis Ababa, Ethiopia, 1999; p. 203.

38. Dinka, M.O. Analysing decadal land use/cover dynamics of the Lake Basaka catchment (Main Ethiopian Rift) using LANDSAT imagery and GIS. Lake Reserv. Res. Manag. 2012, 17, 11-24. [CrossRef]

39. The United Nations Educational, Scientific and Cultural Organization (UNESCO). Groundwater Resources of the World: Transboundary Aquifer Systems 1:50,000,000 Scale; UNESCO: Paris, France, 2006.

40. Kebede, S.; Travi, Y.; Asrat, A.; Alemayehu, T.; Ayenew, T.; Tessema, Z. Groundwater origin \& flow along selected transects in Ethiopian rift volcanic aquifers. J. Hydrol. 2008, 6, 55-73.

41. Ayenew, T. The Hydrogeological System of the Lake District Basin. Central Main Ethiopian Rift. Ph.D. Thesis, Free University of Amsterdam, Amsterdam, The Netherlands, 1998; p. 259.

42. Mohr, P.A. The Geology of Ethiopia; University College of Addis Ababa: Addis Ababa, Ethiopia, 1971.

43. Mohr, P.A. Major volcano-tectonic lineament in the Ethiopian rift system. Nature 1967, $213,664-665$. [CrossRef]

44. Mohr, P.A. Patterns of faulting in the Ethiopian rift valley. Tectonophysics 1987, 143, 169-179. [CrossRef]

45. Halcrow, W. The Study of Beseka Lake Levels. Report for the Government of Ethiopia; Awash Valley Development Agency: San Bernardino, CA, USA, 1978; p. 83.

46. Band, L.E. A terrain-based watershed information system. Hydrol. Process. 1989, 3, 151-162. [CrossRef]

47. Lindsay, J.B.; Rothwell, J.J.; Davies, H. Mapping outlet points used for watershed delineation onto DEM derived stream networks. Water Resour. Res. 2008, 44. [CrossRef]

48. Fontaine, T.A.; Cruickshank, T.S.; Arnold, J.G.; Hotchkiss, R.H. Development of a snowfall-snowmelt routine for mountainous terrain for the Soil Water Assessment Tool (SWAT). J. Hydrol. 2002, 262, 209-223. [CrossRef]

49. Beasley, D.B.; Huggins, L.F.; Monke, E.J. ANSWERS: A model for watershed planning. Trans. ASAE 1980, 23, 938-944. [CrossRef]

50. Tribe, A. Automated recognition of valley lines and drainage networks from grid digital elevation models: A review and a new method. J. Hydrol. 1992, 139, 263-293. [CrossRef]

51. Turcotte, R.; Fortin, J.P.; Rousseau, A.N.; Massicotte, S.; Villeneuve, J.P. Determination of the drainage structure of a watershed using a digital elevation model and a digital river and lake network. J. Hydrol. 2001, 240, 225-242. [CrossRef]

52. ESRI. ArcGIS Desktop Help 9.2; Environmental Systems Research Institute, Inc.: Redlands, CA, USA, 2007. Available online: http:/ / webhelp.esri.com/arcgisdesktop/9.2 (accessed on 25 March 2015).

53. Shuttle Radar Topography Mission (SRTM) Website. Available online: http://www2.jpl.nasa.gov/srtm/ (accessed on 18 July 2015).

54. Lin, C.Y.; Lin, T.W.; Chou, C.W. Soil erosion prediction and sediment yield estimation: The Taiwan experience. Soil Tillage Res. 2002, 68, 143-152. [CrossRef]

55. Jenson, S.K.; Domingue, J.O. Extracting topographic structure from digital elevation data for geographic information system analysis. Photogramm. Eng. Remote Sens. 1988, 54, 1593-1600.

56. Jain, M.K.; Kothyari, U.C. Estimation of soil erosion and sediment yield using GIS. Hydrol. Sci. J. 2000, 45, 771-786. [CrossRef]

57. Kumar, M.; Kumar, R.; Singh, P.K.; Singh, M.; Yadav, K.K.; Mittal, H.K. Catchment delineation and morphometric analysis using geographical information system. Water Sci. Technol. 2015, 72, 1168-1175. [CrossRef] [PubMed]

58. Yihdego, Y.; Webb, J.A.; Vaheddoost, B. Highlighting the Role of Groundwater in Lake-Aquifer Interaction to Reduce Vulnerability and Enhance Resilience to Climate Change. J. Hydrol. 2017, 4, 10. [CrossRef] 
59. Gizaw, B. The origin of high carbonate and fluoride concentrations in waters of the MER Valley, East African Rift system. J. Afr. Earth Sci. 1996, 22, 391-402. [CrossRef]

60. Dilsebo, H. Evaluating the Infield Water Application Performance of Furrow Irrigation System at Matahara Sugar Estate; Research Report submitted to Research and Training Services of the Ethiopian Sugar Industry Support Center; Ethiopian Sugar Industry Support Center: Addis Ababa, Ethiopia, 2004.

61. Bojanowski, A. Africa's New Ocean-A Continent Splits Apart. Online Report on the Website. Available online: http://www.spiegel.de/international/spiegel/africa-s-new-ocean-a-continent-splitsapart-a-405947.html (accessed on 20 July 2010).

(C) 2017 by the author. Licensee MDPI, Basel, Switzerland. This article is an open access article distributed under the terms and conditions of the Creative Commons Attribution (CC BY) license (http://creativecommons.org/licenses/by/4.0/). 